\title{
The Recent Californian Earthquake
}

\section{Author(s): R. D. O.}

Source: The Geographical Journal, Vol. 28, No. 4 (Oct., 1906), pp. 384-385

Published by: geographicalj

Stable URL: http://www.jstor.org/stable/1776518

Accessed: 27-06-2016 08:44 UTC

\section{Your use of the JSTOR archive indicates your acceptance of the Terms \& Conditions of Use, available at}

http://about.jstor.org/terms

JSTOR is a not-for-profit service that helps scholars, researchers, and students discover, use, and build upon a wide range of content in a trusted digital archive. We use information technology and tools to increase productivity and facilitate new forms of scholarship. For more information about JSTOR, please contact support@jstor.org.

The Royal Geographical Society (with the Institute of British Geographers), Wiley are collaborating with JSTOR to digitize, preserve and extend access to The Geographical Journal 
its enormous effect on popular attention to geographical subjects, as well as, or even more than, on exploration.

It must not be inferred that the popularity of a subject is taken by me as a test of its place in the ranks of science; but, owing to the widening of the area from which students can be drawn and men of genius evolved, this democratization of geographical ideas is, to my mind, a very hopeful feature as regards the future of the scientific treatment of the subject.

I should have to extend my address to undue length if I attempted to demonstrate the recent growth of the scientific method at home by giving you even an imperfect catalogue of the geographical books and papers of a scientific nature published during the period under consideration, and especially in later years. I can only select for mention a few typical books, such as Dr. Mill's 'International Geography,' Mr. Mackinder's 'Britain and the British Seas,' Mr. Hogarth's 'Nearer East,' and Sir Thomas Holdich's work on 'India,' and other works in Mr. Mackinder's series entitled 'The Regions of the World.' As to papers dealing with this kind of work, I will mention those by Messrs. Buckman and Strahan, giving the results of their investigations on the river systems of the west of England; by Mr. Cooper Read on the river system of East Yorkshire; by Dr. Herbertson on the major natural regions of the world, and on the distribution of rainfall over the Earth's surface; by Mr. Chisholm on the distribution of towns and villages, and on the geographical conditions affecting British trade; by Messrs. Smith, Lewis, and Moss on the geographical distribution of vegetation in England and Scotland; by Mr. Marr on the waterways of English Lakeland; and last, but not least, by Dr. Mill on the Clyde Sea Area, on a fragment of the geography of England and Wales viewed geographically. It must, indeed, be confessed that in this respect we are still behind Germany, which has been pouring forth a mass of geographical literature of the highest scientific value. But this backwardness is the result of past neglect of the subject, and not of present apathy. There was a current saying a quarter of a century ago that the schoolmaster was abroad. I have shown you that, in a different sense, the geographer was then abroad; but I believe that we may now say that the geographer is at home and has come to stay. There is a whole school of young geographers-not yet very large, but zealous and active-full of the new ideas, the new methods, the new hopes of our rising science, and I do not think it too sanguine to expect that when the British Association holds its centenary meeting, twenty-five years hence, perhaps in this very city of York, our countrymen will be found to occupy the same position in the front rank of scientific geography that their forefathers held in pioneer exploration.

\section{THE RECENT CALIFORNIAN EARTHQUAKE.}

The Commission of Inquiry into the earthquake phenomena in all parts of the state of California, which was appointed immediately after the earthquake of April 18 last, has issued a preliminary report, the most interesting part of which is a description of the proximate cause of the earthquake. The coast ranges of California are crossed obliquely by a peculiar set of surface features, not due to atmospheric or stream erosion, but to a dislocation, or rather a series of dislocations, of the Earth's crust, with a differential movement on either side of the plane of rupture. In general this line follows a system of long narrow valleys, or, where it passes through wide valleys, it lies close to the base of the confining hills; but in some cases it passes over mountain ridges or crosses a spur or shoulder of a mountain. Along this line are abrupt changes in the normal slope of the ground, giving rise to scarps, to small basins or pools, and occasionally to trough-like 
depressions bounded on either side by scarps. In many cases these features have been so modified and softened down by weathering that only the expert eye can detect their abnormal character, but where the line traverses the more desert part of the coast range, as, for example, in the Carissa plains, they are known to the people of the country, and the aggregate of the features is commonly referred to as the "earthquake crack." 'This line has been traced from Point Arena to the vicinity of Mount Pinos, in Ventura county, and is either continued even further to the south-east, or a similar set of features comes in, in echelon, and can be traced to San Jacinto, on the south-east border of the Colorado desert. Leaving the southern extension out of the question, this very remarkable physiographic line has a length of $37 \bar{j}$ miles from Point Arena to Mount Pinos, and crosses obliquely the entire breadth of the coast ranges. Throughout its length it affords every evidence of recurrent differential movements extending far back into the Quaternary period.

The earthquake of April 18 was due to one of these movements, but the extent of the rift along which it took place is not yet fully known. Direct field observations have shown that it extends certainly from the vicinity of San Juan, in San Benito county, to Point Arena, a distance of 185 miles; but the destruction at Petrolia and Ferndale, in Humboldt county, indicates a northerly extension of the rift at least as far as Cape Mendocino, thus making the total length at least 300 miles. Along the 185 miles of this rift, where movement has actually been observed, the displacement has been chiefly horizontal, on a nearly vertical plane, and the county to the south-west of the rift has moved nortl-westerly, relative to the county on the north-east of the rift. The evidence of rupture and differential movement along the line of rift is clear and unequivocal; the surface soil presents a continuous furrow, generally several feet wide, with transverse cracks, showing very plainly the effect of torsion within the zone of the movement; and all roads, fences, pipe, and other lines which cross the rift have been dislocated. The amount of dislocation varies; in several instances it did not exceed 6 feet, a more common measurement is 8 to 10 feet, while in one case a roadway was found to have been moved no less than 20 feet. Probably the mean value is about, 10 feet, and variations from this are due to local causes, such as drag of the mantle of soil upon the rock, or excessive movement of soft incoherent deposits. Besides this general horizontal movement, there is observable in Sonoma and Mendocino counties a differential vertical movement, not exceeding 4 feet, so far as is known, whereby the south-west side of the rift was raised relatively to the north-east side so as to present a low scarp facing the north-east. This vertical movement diminishes to the south-east along the rift-line, and is scarcely, if at all, recognizable in San Mateo county; still further south there are suggestions that this movement may have been in the reverse direction, but this needs further study. As a consequence of this movement, the latitudes and longitudes of the trigonometrical stations occupied by the Coast and Geodetic Survey must have altered to a measurable amount, and the commission expresses a hope that these stations may be reoccupied. From another source we learn that it has been decided to do so, and the re-triangulation is to be carried far enough eastward to connect the redetermined points with stations that may safely be regarded as quite beyond the effect of the recent movement.

The remainder of the preliminary report is devoted to an account of the organization of the investigation and a brief account of the principal facts known; of no great importance in itself, enough is said to show that the earthquake of April 18 is one of those which are likely to add materially to our knowledge of the principles of seismology, and it is gratifying that its investigation should have fallen into such capable hands, and be uncrippled by any lack of funds or workers.

R. D. O. 